\title{
Seasonality of Lutzomyia intermedia and Lutzomyia whitmani (Diptera: Psychodidae: Phlebotominae), Occurring Sympatrically in Area of Cutaneous Leishmaniasis in the State of Rio de Janeiro, Brazil
}

\author{
Nataly A Souza/ ${ }^{+}$, Claudia A Andrade-Coelho, Maurício L Vilela, Alexandre A Peixoto*, \\ Elizabeth F Rangel
}

\begin{abstract}
Departamento de Entomologia *Departamento de Bioquímica e Biologia Molecular, Instituto Oswaldo Cruz-Fiocruz, Av. Brasil
\end{abstract} 4365, 21045-900 Rio de Janeiro, RJ, Brasil

Lutzomyia intermedia and Lutzomyia whitmani occur sympatrically in the district of Posse, municipality of Petrópolis, in the State of Rio de Janeiro (114 km from the city of Rio de Janeiro), where sand flies were captured weekly for three consecutive years in both the peridomicile and forest, in two first years from 18:00 to 22:00 h, using a Shannon trap and CDC light traps. The anthropophilic habit was assessed by recording the specimens that bit the human captors. Considering the different capture types and sites, the following species were identified: Brumptomyia brumpti, B. cardosoi, B. guimaraesi, Lutzomyia amarali, L. longipalpis, L. microps, L. costalimai, L. edwardsi, L. firmatoi, L. migonei, L. termitophila, L. tupynambai, L. fischeri, L. pessoai, L. lutziana, L. shannoni, L. barrettoi, L. intermedia, L. whitmani, L. lloydi, and L. minasensis. L. intermedia (38.3\%) and L. whitmani (38.6\%) predominated. L. intermedia predominated in the peridomicile, where it displayed more intense anthropophily, while L. whitmani displayed greater density in the banana plantations and forest, preferential sites for biting humans. Studies on seasonality showed that while L. intermedia displayed greater density in the hottest months of the year (December, January, and February), L. whitmani was abundant in the coolest months (June, July, and August), although both occurred throughout the year.

Keys words: Lutzomyia intermedia - Lutzomyia whitmani - sand fly fauna - seasonality - sympatric species -

Rio de Janeiro - Brazil

Foci of American cutaneous leishmaniasis (ACL) in the State of Rio de Janeiro have been described since the beginning of the last century. In the last 25 years, several outbreaks have been reported in different places, related to new human settlements in recently deforested areas. This epidemiological profile has been observed mainly in the Southeast of Brazil, and peridomiciliary transmission should be considered in these cases (Rangel 1995). Currently it is possible to observe the disease around metropolitan areas, where the Atlantic Forest has been devastated over the course of the years.

Lutzomyia intermedia (Lutz \& Neiva, 1912) is probably the main vector of Leishmania (Viannia) braziliensis in the State of Rio de Janeiro (Aragão 1922, Nery-Guimarães 1955, Menezes et al. 1974, Araújo-Filho 1978, Sabroza 1981, Coutinho et al. 1981, Rangel et al. 1984, 1986, 1990), with a domiciliary and peridomiciliary transmission cycle.

In 1996, we were informed by the Center for Zoonoses of the Petrópolis Municipal Health Department about the occurrence of human cases [due to L.(V.) braziliensis], dogs with high serum titers, and dogs and horses with

This work was supported by Fiocruz and CNPq with additional support from The Wellcome Trust.

${ }^{+}$Corresponding author. Fax: +55-21-2290.9339. E-mail: souzana@ioc.fiocruz.br

Received 1 October 2001

Accepted 29 April 2002 suspicious lesions in the district (township) of Posse, in the northern region of the municipality (county) of Petrópolis, in the State of Rio de Janeiro.

Preliminary studies on the sand fly fauna showed the simultaneous occurrence of L. intermedia and L. whitmani (Antunes \& Coutinho 1939), apparently for the first time, with a similar density and being a more aggressive manbiter than L. intermedia in the same transmission area for cutaneous leishmaniasis in the State of Rio de Janeiro.

Therefore, the aim of this study, besides the knowledge of local sand fly species, was to analyze aspects related to the seasonality and anthropophilic behaviour of L. intermedia and L. whitmani, evaluating the possibility of these vector species to be sharing the transmission mechanism for L. (V.) braziliensis in the region.

\section{MATERIALS AND METHODS}

Study area - The district of Posse is a rural area in the northern part of the municipality of Petrópolis, $112 \mathrm{~km}$ from the city of Rio de Janeiro (Fig. 1). In the past, this area was covered by primary forest, while currently, due to heavy anthropic activity, a major portion of the native forest has been replaced by farm crops and especially pasture.

Due to its geographic location and relief, the area is classified as having a super-humid and humid mild mesothermic tropical climate. This type of climate occurs in the Serra do Mar mountain range, where the altitude is $700 \mathrm{~m}$ above sea level, which is the case for the area under study. Annual mean temperatures vary between $18^{\circ}$ and 

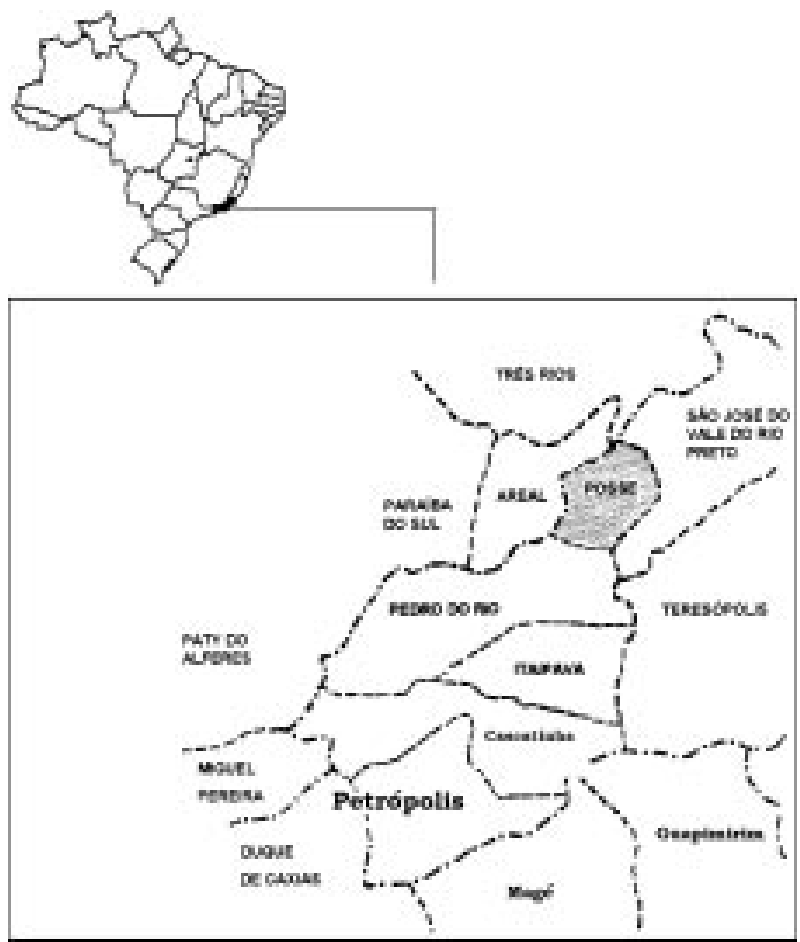

Fig. 1: district of Posse, Petropólis municipality, State of Rio de Janeiro, Brazil.

$19^{\circ} \mathrm{C}$, and even during the summer the mean temperatures are rarely over $20^{\circ} \mathrm{C}$. During the winter the mean minimum temperature falls to $10^{\circ} \mathrm{C}$ (National Department of Water and Electric Power, National Institute of Meteorology).

The district of Posse is located in an area of the Serra do Mar where rocky outcroppings indicate abundant presence of granite and gneiss, in various stretches of the mountain range.

Our capture station was set up on the "Sítio Catavento" (Windmill Farm), where a human case of leishmaniasis due to $L$. (V.) braziliensis had been diagnosed.

Capture sites - To conduct the survey of sand fly fauna, local distribution of species by type of capture, activity, seasonality, and anthropophilic habit, we used two capture stations: Station 1 (peridomicile): anthropic areas, recent deforestation, with human dwellings, shelters for domestic animals (a chicken coop and kennel), and fruit trees, where bananas were the most abundant fruit crop. Station 2 (forest): part of the farm is covered by mountainous semidecidual seasonal forest (primary and secondary vegetation in the early, medium and advanced stages of regeneration of the Atlantic Rain Forest, in the State of Rio de Janeiro by report of the Municipal Government of Petrópolis). This type of vegetation is conditioned by a double climatic seasonality, including one tropical season with heavy summer rains followed by an intense drought, and the other subtropical, without a proper dry period, but with a physiological drought caused by the cold winter temperature. The climates establish a foliar seasonality in the dominant arboreal species, which adapt to the alternating lack of water and drop in temperature in the cold months. The predominant smaller plant and shrub species are the following: "romerillo" (Baccharis dracunculifolia), "assa-peixe" (Vernonia polyanthes); "lantana" (Lantana camara); rattlesnake fern (Crotalaria mucronatal); "erva-colégio" (Elephantopus mollis); nightshade (Solanum aculeaisum); "jurubeba" (Solanum paniculatum); "pindova" (Atalea humilis); "pixirica" (Clidemia hirta); and "sape" grass (Imperata brasiliensis). The most frequent ligneous species indicative of this stage in the area are: "angico" (Anadenanthera colubrina); "crindiúva" (Trema micrantha); trumpetwood (Cecropia spp.); "marica" (Mimosa bimucromata); and "sangue-de-dragrão" (Croton urucuana). The vines are predominantly ligneous. The following species are also present: "açoita-cavalo" (Luheta grandiflora); "tecoma" (Tabebuia chrisotricha); and "senna" (Senna multijuga) (Municipal Government of Petrópolis).

A comparative entomological survey of the two areas (located $200 \mathrm{~m}$ apart) was conducted weekly for two consecutive years, from 18:00 to 22:00 $\mathrm{h}$. The data presented in the table and figures represents the sum of the four captures performed each month.

Captures in the domicile and peridomicile - Station 1 employed three CDC light traps (Sudia \& Chamberlain 1962): one in the chicken coop, another on the outside wall of the house (10 m apart), and a third one in the banana grove ( $80 \mathrm{~m}$ from the house). Active captures on the outside wall of the house were conducted on the opposite side from where the light trap was placed. Attraction to human bait was evaluated together with the captures on the walls of the house. Species found biting human captors were separated from those captured on the walls.

Captures in the forest - Station 2 included CDC light traps at different points: one on the slope close to crevices in the rocks; another in a small cave; and a third one above the tabular roots of mature trees (located $15 \mathrm{~m}$ apart from each other). A Shannon trap (Shannon 1939, Alexander 2000) was also used to capture sand flies $245 \mathrm{~m}$ from the house.

Sand fly identification - The specimens captured and fixed in alcohol at 70\% underwent a process and were mounted on microscope slides with slide covers and fixed in Berlese liquid. Identification of specimens was performed using the classification proposed by Young and Duncan (1994).

Data analysis - Analysis of variance, investigating the effect of seasonal and microgeographic variation and the different capture types on the relative frequencies of $L$. intermedia and $L$. whitmani was conducted after angular transformation. Captures performed in the same months in different years were treated as replicates. Analysis of the association between the number of sand flies captured in the two years and environmental variables (precipitation and high and low temperatures) used Spearman's rank correlation (Sokal \& Rohlf 1995).

\section{RESULTS}

Sand fly fauna - In $384 \mathrm{~h}$, a total of 45,170 sand flies were captured: 19,365 females and 25,805 males, considering the different months, capture sites, and types of cap- 
ture. Three species of Brumptomyia (França \& Parrot 1921) and 20 species of Lutzomyia (França 1924) were listed. $L$. intermedia $(38.3 \%)$ and L. whitmani $(38.6 \%)$ predominated, with other species displaying low percentages (Table I).

Table II presents the capture data from Station 1, demonstrating that $L$. intermedia was the predominant species in the peridomicile (57.7\%) where it was the most anthropophilic species followed by L. whitmani (22.6\%) (Fig.2), and it is important to highlight that both were captured on the walls of the house. L. migonei, L. fisheri, and $L$. quinquefer were also present in the peridomicile, although in smaller proportions. However, in the banana grove $L$. whitmani predominated over $L$. intermedia, and there was also a greater diversity of sand fly species.

In Station 2, located in the forest, there was a major

TABLE I

Sand fly fauna in Posse, State of Rio de Janeiro: number and percentage of collected sand fly species in different areas. July 1996 to June 1998

\begin{tabular}{|c|c|c|c|c|}
\hline \multirow[b]{3}{*}{ Species } & \multicolumn{4}{|c|}{ Results } \\
\hline & \multicolumn{2}{|c|}{ Number collected } & \multirow[b]{2}{*}{ Total } & \multirow[b]{2}{*}{ Percentage } \\
\hline & $\mathrm{F}$ & M & & \\
\hline Brumptomyia brumpti (Larrousse, 1920) & 43 & 65 & 108 & 0.2 \\
\hline B. cardosoi (Barretto \& Coutinho,1941) & 22 & 23 & 45 & 0.1 \\
\hline B. guimaraesi (Coutinho \& Barretto,1941) & 37 & 26 & 63 & 0.1 \\
\hline Lutzomyia amarali (Barretto \& Coutinho, 1940) & 31 & 37 & 68 & 0.2 \\
\hline L. longipalpis (Lutz \& Neiva, 1912) & 11 & 24 & 35 & 0.1 \\
\hline L. microps (Mangabeira,1942) & 26 & 30 & 56 & 0.1 \\
\hline L. costalimai (Mangabeira,1942) & 18 & 61 & 79 & 0.2 \\
\hline L. edwardsi (Mangabeira, 1942) & 46 & 60 & 106 & 0.2 \\
\hline L. firmatoi (Barretto,Martins \& Pellegrino,1956) & 37 & 68 & 105 & 0.2 \\
\hline L. migonei (França, 1920) & 697 & 1,059 & 1,756 & 3.9 \\
\hline L. termitophila Martins, Falcão \& Silva, 1964 & 10 & 22 & 32 & 0.1 \\
\hline L. tupynambai (Mangabeira, 1942) & 90 & 88 & 178 & 0.4 \\
\hline L. fischeri (Pinto,1926) & 1,764 & 2,275 & 4,039 & 8.9 \\
\hline L. pessoai (Coutinho \& Barreto,1940) & 24 & 22 & 46 & 0.1 \\
\hline L. lutziana (Costa Lima,1932) & 12 & 20 & 32 & 0.1 \\
\hline L. shannoni (Dyar,1929) & 22 & 46 & 68 & 0.2 \\
\hline L. barrettoi (Mangabeira, 1942) & 123 & 131 & 254 & 0.6 \\
\hline L. intermedia (Lutz \& Neiva,1912) & 7,548 & 9,749 & 17,297 & 38.3 \\
\hline L. whitmani (Antunes \& Coutinho, 1939) & 7,507 & 9,930 & 17,437 & 38.6 \\
\hline L. lloydi (Antunes, 1937) & 32 & 41 & 73 & 0.2 \\
\hline L. minasensis (Mangabeira,1942) & 35 & 39 & 74 & 0.2 \\
\hline L. quinquefer (Dyar, 1929) & 531 & 1,286 & 1,817 & 4.0 \\
\hline L. monticola (Costa Lima,1932) & 699 & 703 & 1,402 & 3.1 \\
\hline Total & 19,365 & 25,805 & 45,170 & 100 \\
\hline
\end{tabular}

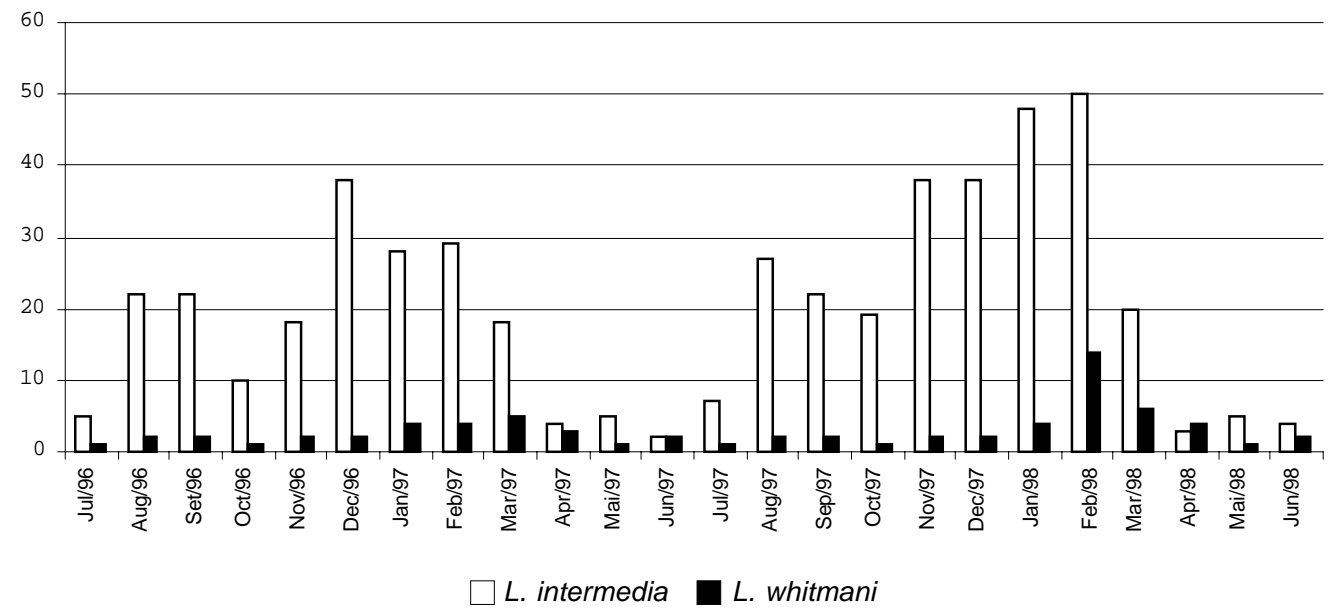

Fig. 2: collected Lutzomyia intermedia and Lutzomyia whitmani on human bait in peridomicile. 
predominance of $L$. whitmani (63.5\%) in all types of captures and it was also its preferential site for biting humans (Fig. 3). The second most frequently captured species was L. fisheri (14.6\%), which occurred preferentially in this environment. L. intermedia was also present in the forest, but with a lower density (7.9\%) (Table III).

Observations pertaining to sand fly seasonality showed that while L. intermedia predominated in the hottest months of the year (December, January, and February), L. whitmani was abundant in the coolest months (June, July, and August), although both were present throughout the year (Fig. 4). This seasonal fluctuation was confirmed by the highly significant correlations between the number of sand flies of the two species captured monthly during the two study years (L. intermedia, $\mathrm{R}=0.81, \mathrm{p}<0.002 ;$ L. whitmani, $\mathrm{R}=0.98, \mathrm{p}<0.0001$ ). Temperature and precipitation data provided by the National Institute of Meteorology demonstrate this seasonality (Fig. 2), and significant correlations were present between the number of specimens from the two species and these environmental variables (Table IV).

Analysis of variance was conducted, comparing the relative frequency of $L$. intermedia in different months and types of capture. The results indicate highly significant effects for the month $\left(F_{[11.1082}=27.43 ; P<0.0001\right)$ and type of capture $\left(F_{[8,108]}=206.29 ; P<0.0001\right)$, as well as for interaction between the two $\left(F_{[88,108]}=6.34 ; P<\right.$
0.0001). Similar results were obtained for $L$. whitmani (month: $F_{[11,108]}=73.02 ; P<0.0001$; type of capture: $F_{[8,108]}=195.76 ; P<0.0001$; and interaction: $F_{[88,108]}=$ $8.97 ; P<0.0001)$. Likewise, significant effects for capture site and season of the year were observed when the months of the year were divided ("nested analysis") into two seasons (October-March, hot and rainy; April-September, cold and dry) and the captures were divided into peridomicile and forest. Thus, these results indicate the occurrence of microgeographic and seasonal variation in the relative frequencies of the two species.

Seasonal and microgeographic variations in the numbers of L. intermedia and L. whitmani have an important effect on the probability of humans being bitten by one of these two vectors, depending on the area and time of year, where the number of sand flies from the two species and captured with human bait over the two years is shown for both the peridomicile (Fig. 3) and the forest (Fig. 4).

\section{DISCUSSION}

Since the beginning of the last century in Rio de Janeiro $L$. intermedia has been considered as a vector of cutaneous leishmaniasis. Aragão (1922), based on the association between a high density of L. intermedia and the presence of the disease in Águas Férreas in the Laranjeiras neighborhood, incriminated this sand fly as the potential vector of $L$. ( V.) braziliensis in the Southeast of Brazil.

\section{TABLE II}

Sand fly fauna in Posse, State of Rio de Janeiro: number and percentage of collected species in peridomiciliary area. July 1996 to June 1998

\begin{tabular}{|c|c|c|c|c|c|c|c|c|c|c|c|c|c|}
\hline \multirow[b]{3}{*}{ Species } & & & & & & & & \multicolumn{2}{|c|}{ Banana plantation } & \multicolumn{4}{|c|}{ Results } \\
\hline & \multicolumn{2}{|c|}{$\begin{array}{l}\text { Walls of } \\
\text { houses }\end{array}$} & \multicolumn{2}{|c|}{$\begin{array}{c}\text { CDC } \\
\text { light trap }\end{array}$} & \multicolumn{2}{|c|}{$\begin{array}{l}\text { CDC light trap } \\
\text { in chicken coop }\end{array}$} & \multirow{2}{*}{$\begin{array}{c}\begin{array}{c}\text { Human } \\
\text { bait }\end{array} \\
\mathrm{F}\end{array}$} & \multicolumn{2}{|c|}{$\begin{array}{c}\text { CDC } \\
\text { light trap }\end{array}$} & \multicolumn{2}{|c|}{$\begin{array}{l}\text { Number } \\
\text { collected }\end{array}$} & \multirow[b]{2}{*}{ Total } & \multirow{2}{*}{$\begin{array}{c}\text { Percen- } \\
\text { tage }\end{array}$} \\
\hline & $\mathrm{F}$ & $\mathrm{M}$ & $\mathrm{F}$ & M & $\mathrm{F}$ & M & & $\mathrm{F}$ & M & $\mathrm{F}$ & M & & \\
\hline B. brumpti & 0 & 0 & 0 & 0 & 0 & 0 & 0 & 7 & 9 & 7 & 9 & 16 & 0.1 \\
\hline B. cardosoi & 0 & 0 & 2 & 0 & 0 & 0 & 0 & 0 & 3 & 2 & 3 & 5 & 0.0 \\
\hline B. guimaraesi & 0 & 0 & 3 & 0 & 0 & 0 & 0 & 1 & 4 & 4 & 4 & 8 & 0.0 \\
\hline L. amarali & 0 & 0 & 0 & 2 & 0 & 0 & 0 & 6 & 1 & 6 & 3 & 9 & 0.0 \\
\hline L. longipalpis & 2 & 2 & 1 & 0 & 5 & 17 & 0 & 0 & 1 & 8 & 20 & 28 & 0.1 \\
\hline L. microps & 0 & 0 & 0 & 0 & 0 & 0 & 0 & 0 & 0 & 0 & 0 & 0 & 0.0 \\
\hline L. costalimai & 0 & 8 & 0 & 0 & 0 & 0 & 0 & 4 & 16 & 4 & 24 & 28 & 0.1 \\
\hline L. edwardsi & 0 & 0 & 0 & 0 & 0 & 0 & 0 & 23 & 25 & 23 & 25 & 48 & 0.2 \\
\hline L. firmatoi & 3 & 3 & 0 & 5 & 1 & 0 & 0 & 4 & 18 & 8 & 26 & 34 & 0.1 \\
\hline L. migonei & 42 & 139 & 35 & 54 & 297 & 527 & 26 & 86 & 108 & 486 & 828 & 1,314 & 4.8 \\
\hline L. termitophila & 0 & 0 & 0 & 0 & 7 & 12 & 0 & 1 & , & 8 & 15 & 23 & 0.1 \\
\hline L. tupynambai & 6 & 5 & 0 & 0 & 0 & 0 & 0 & 16 & 15 & 22 & 20 & 42 & 0.2 \\
\hline L. fischeri & 44 & 264 & 26 & 44 & 146 & 203 & 21 & 300 & 421 & 537 & 932 & 1,469 & 5.3 \\
\hline L. pessoai & 0 & 0 & 0 & 1 & 0 & 0 & 0 & 0 & 0 & 0 & 1 & 1 & 0.0 \\
\hline L. lutziana & 0 & 0 & 0 & 0 & 0 & 0 & 0 & 0 & 0 & 0 & 0 & 0 & 0.0 \\
\hline L. shannoni & 0 & 1 & 0 & 0 & 0 & 0 & 0 & 4 & 8 & 4 & 9 & 13 & 0.0 \\
\hline L. barrettoi & 0 & 0 & 0 & 0 & 11 & 5 & 0 & 32 & 24 & 43 & 29 & 72 & 0.3 \\
\hline L. intermedia & 621 & 1,872 & 939 & 1,652 & 3,908 & 4,220 & 482 & 986 & 1,230 & 6,936 & 8,974 & 15,910 & 57.8 \\
\hline L. whitmani & 122 & 403 & 83 & 195 & 294 & 400 & 70 & 1,900 & 2,769 & 2,469 & 3,767 & 6,236 & 22.6 \\
\hline L. lloydi & 0 & 2 & 0 & 0 & 0 & 0 & 0 & 11 & 12 & 11 & 14 & 25 & 0.1 \\
\hline L. minasensis & 0 & 0 & 4 & 3 & 0 & 0 & 0 & 4 & 7 & 8 & 10 & 18 & 0.1 \\
\hline L. quinquefer & 315 & 929 & 61 & 129 & 125 & 186 & 1 & 29 & 38 & 531 & 1,282 & 1,813 & 6.6 \\
\hline L. monticola & 12 & 0 & 0 & 0 & 12 & 0 & 0 & 171 & 237 & 195 & 237 & 432 & 1.6 \\
\hline Total & 1,167 & 3,628 & 1,154 & 2,085 & 4,806 & 5,570 & 600 & 3,585 & 4,949 & 11,312 & 16,232 & 27,544 & 100 \\
\hline
\end{tabular}

B: Brumptomyia; L: Lutzomyia 


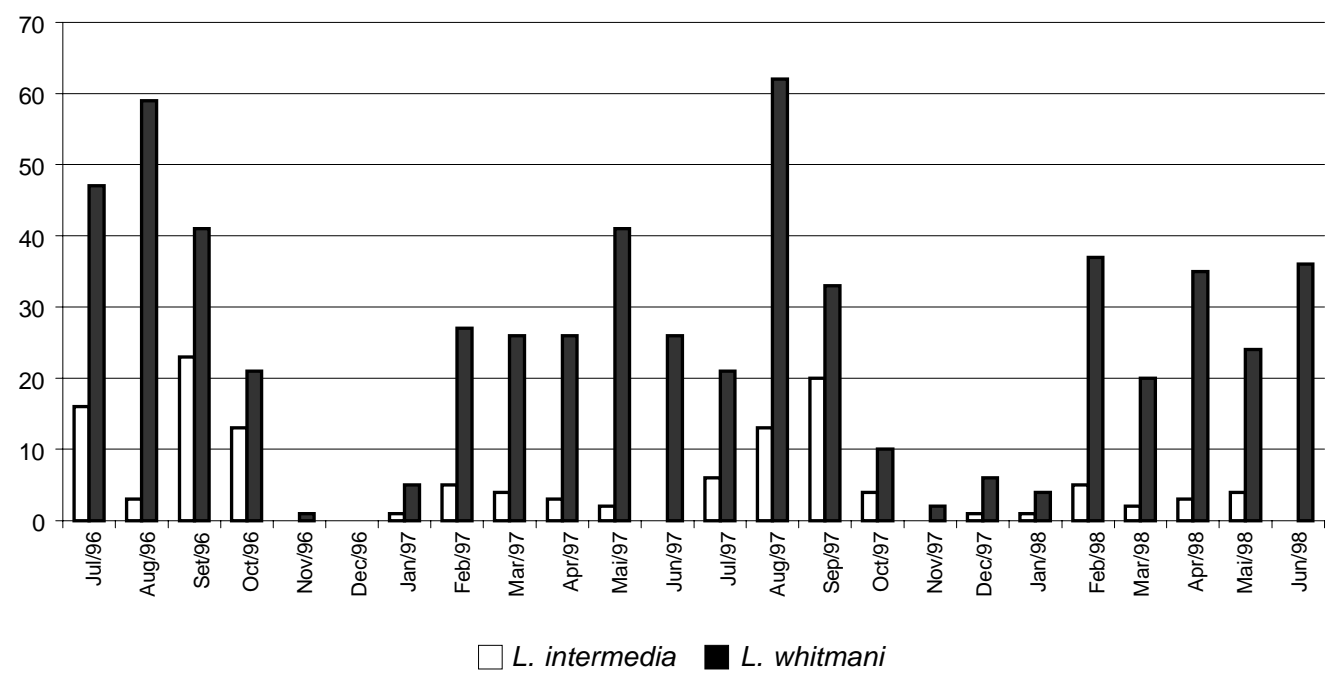

Fig. 3: collected Lutzomyia intermedia and Lutzomyia whitmani on human bait in the forest.

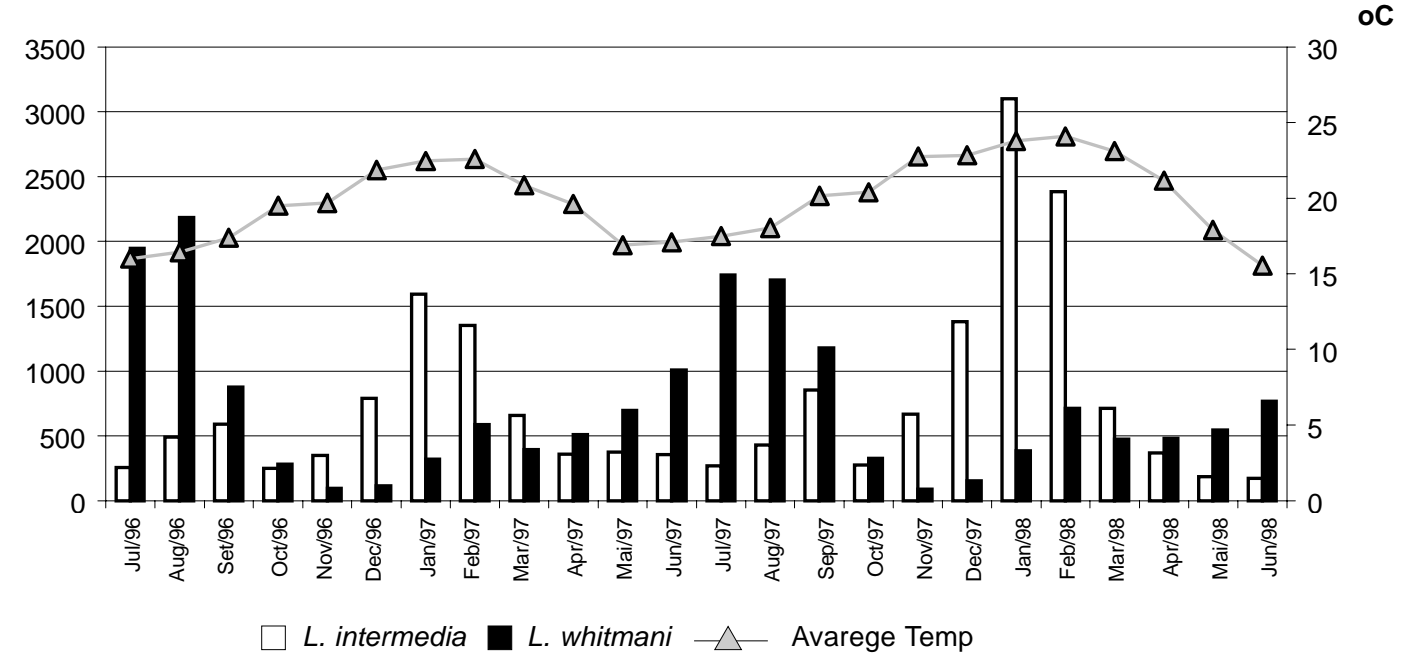

Fig. 4: seasonal variation of collected Lutzomyia intermedia and Lutzomyia whitmani in the peridomicile and in the forest.

Data from different studies have shown a significant percentage of this species in the domicile and peridomicile. Although being the more aggressive man-biter, $L$. intermedia appears to be strongly attracted by dogs and horses, suggested as secondary reservoirs of $L$. (V.) braziliensis (Menezes et al. 1974, Araújo Filho 1978, Sabroza 1981, Coutinho et al. 1981, Rangel et al. 1986, 1990, 1998).

L. intermedia appears to play an important role in the transmission mechanism of ACL in the states of Espírito Santo, São Paulo, and Rio de Janeiro. It has been found naturally infected with Leishmania, presumably $L$. (V.) braziliensis, in the states of Paraná (Forattini \& Santos 1952), São Paulo (Forattini et al. 1972), and Rio de Janeiro (Rangel et al. 1984).

The first references to the role of $L$. whitmani as a vector of leishmaniasis date to the early $40 \mathrm{~s}$, based on studies in the Southeast region of Brazil, when Pessoa and Coutinho (1940) found specimens of L. whitmani naturally infected with flagellates, presumably Leishmania, in São Paulo. In the Southeast of Brazil, the species has been found with a high density in endemic areas in the states of São Paulo, Minas Gerais, and Espírito Santo. Its presence has been recorded in animal shelters and the domicile and peridomicile.

In Rio de Janeiro, to date, the frequency of $L$. whitmani has always been recorded with low indices (Rangel et al. 1986, 1990, Carvalho 1993, Aguiar et al. 1993). More recent studies have identified $L$. whitmani in preserved areas, as well as in shelters for domestic animals, and it is also the second most frequent species to bite humans in the peridomicile (Souza et al. 2001). De Souza et al. (1995) in São José do Vale do Rio Preto, a neighbour municipality to our capture area (Fig. 1), showed L. whitmani as the second most frequently captured species, next to $L$. intermedia. 
TABLE III

Sand fly fauna of Posse, Rio de Janeiro State: number and percentage of species caught in the forest. July 1996 to June 1998

\begin{tabular}{|c|c|c|c|c|c|c|c|c|c|c|c|}
\hline \multirow[b]{3}{*}{ Species } & \multicolumn{6}{|c|}{ In forest } & \multirow{3}{*}{$\begin{array}{c}\text { Human } \\
\text { bait } \\
\text { F }\end{array}$} & \multicolumn{4}{|c|}{ Results } \\
\hline & \multicolumn{2}{|c|}{$\begin{array}{c}\text { Shannon } \\
\text { trap }\end{array}$} & \multicolumn{2}{|c|}{$\begin{array}{c}\text { CDC } \\
\text { light trap }\end{array}$} & \multicolumn{2}{|c|}{$\begin{array}{l}\text { CDC light trap } \\
\text { in the cave }\end{array}$} & & \multicolumn{2}{|c|}{$\begin{array}{l}\text { Number } \\
\text { collected }\end{array}$} & \multirow[b]{2}{*}{ Total } & \multirow[b]{2}{*}{ Percentage } \\
\hline & $\mathrm{F}$ & M & $\mathrm{F}$ & M & $\mathrm{F}$ & M & & $\mathrm{F}$ & M & & \\
\hline B. brumpti & 3 & 3 & 5 & 9 & 28 & 44 & 0 & 36 & 56 & 92 & 0.5 \\
\hline B. cardosoi & 2 & 3 & 9 & 9 & 9 & 8 & 0 & 20 & 20 & 40 & 0.2 \\
\hline B. guimaraesi & 2 & 2 & 6 & 6 & 25 & 14 & 0 & 33 & 22 & 55 & 0.3 \\
\hline L. amarali & 12 & 14 & 1 & 6 & 12 & 14 & 0 & 25 & 34 & 59 & 0.3 \\
\hline L. longipalpis & 0 & 2 & 3 & 2 & 0 & 0 & 0 & 3 & 4 & 7 & 0.0 \\
\hline L. microps & 10 & 15 & 4 & 2 & 12 & 13 & 0 & 26 & 30 & 56 & 0.3 \\
\hline L. costalimai & 2 & 6 & 0 & 11 & 12 & 20 & 0 & 14 & 37 & 51 & 0.3 \\
\hline L. eduardsi & 13 & 14 & 8 & 20 & 2 & 1 & 0 & 23 & 35 & 58 & 0.3 \\
\hline L. firmatoi & 20 & 20 & 0 & 0 & 9 & 22 & 0 & 29 & 42 & 71 & 0.4 \\
\hline L. migonei & 149 & 152 & 50 & 79 & 0 & 0 & 12 & 211 & 231 & 442 & 2.5 \\
\hline L. termitophila & 0 & 2 & 0 & 2 & 2 & 3 & 0 & 2 & 7 & 9 & 0.1 \\
\hline L. tupynambai & 31 & 37 & 14 & 21 & 23 & 10 & 0 & 68 & 68 & 136 & 0.8 \\
\hline L. fischeri & 730 & 935 & 215 & 241 & 102 & 167 & 180 & 1,227 & 1,343 & 2,570 & 14.6 \\
\hline L. pessoai & 22 & 17 & 2 & 1 & 0 & 3 & 0 & 24 & 21 & 45 & 0.3 \\
\hline L. lutziana & 5 & 9 & 4 & 7 & 3 & 4 & 0 & 12 & 20 & 32 & 0.2 \\
\hline L. shannoni & 10 & 17 & 2 & 7 & 6 & 13 & 0 & 18 & 37 & 55 & 0.3 \\
\hline L. barrettoi & 13 & 32 & 40 & 45 & 27 & 25 & 0 & 80 & 102 & 182 & 1.0 \\
\hline L. intermedia & 242 & 358 & 163 & 290 & 77 & 127 & 130 & 612 & 775 & 1,387 & 7.9 \\
\hline L. whitmani & 2,645 & 3,369 & 1,117 & 1,827 & 660 & 967 & 616 & 5,038 & 6,163 & 1,1201 & 63.5 \\
\hline L. lloydi & 9 & 8 & 3 & 1 & 9 & 18 & 0 & 21 & 27 & 48 & 0.3 \\
\hline L. minasensis & 5 & 7 & 2 & 5 & 20 & 17 & 0 & 27 & 29 & 56 & 0.3 \\
\hline L. quinquefer & 0 & 0 & 0 & 4 & 0 & 0 & 0 & 0 & 4 & 4 & 0.0 \\
\hline L. monticola & 221 & 239 & 50 & 47 & 122 & 180 & 111 & 504 & 466 & 970 & 5.5 \\
\hline Total & 4,146 & 5,261 & 1,698 & 2,642 & 1,160 & 1,670 & 1,049 & 8,053 & 9,573 & 17,626 & 100 \\
\hline
\end{tabular}

B: Brumptomyia; L: Lutzomyia

\section{TABLE IV}

Sperman Correlation (R) between the number of collected Lutzomyia intermedia (INTER) and Lutzomyia whitmani (WHITM) species and the environmental variations: monthly average of the highest temperature (TEMPMAX); monthly average of the lowest temperature (TEMPMIN) and monthly precipitation (PREC). July 1996 to June 1998

\begin{tabular}{lcc}
\hline & $\mathrm{R}$ & $\mathrm{P}$ \\
\hline INTER \& TEMPMAX & .777198 & .000008 \\
INTER \& TEMPMIN & .747444 & .000027 \\
WHITM \& TEMPMAX & -.537424 & .006763 \\
WHITM \& TEMPMIN & -.708723 & .000106 \\
WHITM \& PREC & -.706087 & .000116 \\
\hline
\end{tabular}

In the district of Posse, L. whitmani was the second most frequently captured species, next to L. intermedia. Both species were present in the peridomicile. L. whitmani was the most frequent species in the banana grove, a transition area between the farm dwellings and the forest, and second the most frequently captured species on the walls of the house, showing the possibility of a certain degree of domiciliation, as occurs in other areas in the Northeast, Southeast, and South of Brazil. Considering both capture sites, it was the species that most frequently bit humans.
Barreto (1943) observed that L. whitmani was found more frequently in forest areas undergoing deforestation, although it invaded the domicile and was highly anthropophilic, in addition to avidly biting domestic animals. Its participation in the domicile was confirmed by Forattini (1960), who observed both L. intermedia and L. whitmani as predominant species during deforestation of primary forest. As the deforestation extended, there was a tendency for L. whitmani to disappear, suggesting that this species is more dependent on the primary forest than $L$. intermedia.

In the epidemiological model emerging from deforestation, the non-forest environment stands out, consisting mainly of the extra-domiciliary environment. In this new ecological situation, studies have demonstrated that the transmission of the parasite appears to depend on some species, highlighting L. whitmani and L. intermedia (Forattini et al. 1976, Taniguchi et al. 1991, Stolf et al. 1993).

L. intermedia and L. whitmani have been suggested as important vectors of cutaneous leishmaniasis in various regions of Brazil, demonstrating they are highly anthropophilic and abundant, in addition to natural infection with L.(V.) braziliensis. The data we obtained on seasonality, where L. intermedia predominates in the summer and L. whitmani in the winter, considering their seasonal habits as it was shown in this study, we suggest that the transmission may happen all over the year in this locality. 


\section{ACKNOWLEDGMENTS}

To Ms Deise Aparecida Barrichelo, owner of the Sítio Catavento farm where the study was conducted, for her constant support and encouragement, and Mr Luís Henrique Costa for his technical support in the field and laboratory.

\section{REFERENCES}

Aguiar GM, Medeiros WM, Santos TG, Klein AFL, Ferreira VA 1993. Ecology of cutaneous leishmaniasis in Paraty, littoral of Rio de Janeiro State (Diptera, Psychodidae, Phlebotominae). Mem Inst Oswaldo Cruz 88: 339-340.

Alexander B 2000. Sampling methods for phlebotomine sandflies. Med Vet Entomol 14: 109-122.

Aragão HB 1922. Transmissão da leishmaniose tegumentar no Brasil pelo Phlebotomus intermedius. Bras Méd 36: 129130.

Araújo Filho NA 1978. Epidemiologia da Leishmaniose Tegumentar na Ilha Grande, MSc Thesis, Universidade Federal do Rio de Janeiro, Rio de Janeiro, 148 pp.

Barreto MP 1943. Observações sobre a Biologia em Condições Naturais dos Flebótomos do Estado de São Paulo (Diptera:Psychodidae), PhD Thesis, Universidade de São Paulo, São Paulo, 162 pp.

Carvalho RW 1993. Fauna de Flebótomos (Diptera,Psychodidae) na Ilha do Araujo, Município de Paraty, Estado do Rio de Janeiro, MSc Thesis, Universidade Federal Rural do Rio de Janeiro, Rio de Janeiro, 99 pp.

Coutinho SG, Marzochi MCA, Souza WJS, Amendoeira MRR 1981. Leishmaniose tegumentar americana. J Bras Med 41: 104-118.

De Souza MB, Marzochi MCA, Carvalho RW, Conceição NF, Ponte CS 1995. Flebótomos em áreas de ocorrência de leishmaniose tegumentar no município de São José do Vale do Rio Preto, Rio de Janeiro, Brasil. Parasitol al Dia (Flap): 97-103.

Forattini OP 1960. Novas observações sobre a biologia de flebótomos em condições naturais (Diptera:Psychodidae). Arch Hyg Saúde Publ 25: 209-215.

Forattini OP, Santos MR 1952. Nota sobre infecção natural de Phlebotomus intermedius Lutz \& Neiva, 1912, por formas em leptomonas, em foco de leishmaniose tegumentar americana. Arch Hyg Saúde Publ 17: 171-174.

Forattini OP, Pattoli DBG, Rabello EX, Ferreira OA 1972. Infecções naturais de mamíferos silvestres em área endêmica de leishmaniose tegumentar do Estado de São Paulo, Brasil. Rev Saúde Pública, 6: 255-261.

Forattini OP, Rabello EX, Serra OP, Contrim MD, Galati EA, Barata JM 1976. Transmission of cutaneous leishmaniasis in the State of São Paulo, Brazil. Rev Saúde Pública 10: 3143.

Menezes JA, Reis VLL, Vasconcellos JA 1974. Pequeno surto de leishmaniose tegumentar americana em Macuco (Cordeiro-RJ). Rev Soc Bras Med Trop 8: 113-151.

Nery-Guimarães F 1955. Estudo de um foco de leishmaniose mucocutânea na Baixada Fluminense (Estado do Rio de Janeiro). Mem Inst Oswaldo Cruz, 53: 1-11.

Pessoa SB, Coutinho JO 1940. Infecção natural de Phlebotomus pessoai por formas em leptomonas, provavelmente da Leishmania braziliensis. Rev Biol Hig 10: 139-142.

Rangel EF 1995 Tropical Diseases, Society and the Environment. SAREC Documentation/TDR, p. 103-110.

Rangel EF, Azevedo ACR, Andrade CA, Souza NA, Wermelinger ED 1990. Studies on sandfly fauna (Diptera: Psychodidae) in a focus of cutaneous leishmaniasis in Mesquita, Rio de Janeiro State, Brazil. Mem Inst Oswaldo Cruz 85: 39-45.

Rangel EF, Meneses CR, Azevedo AC, Franco A, Mayrink A, Grimaldi FG 1998. Leishmaniose cutânea no Estado do Rio de Janeiro, Brasil: ciclo silvestre e a ligação com peridomicílio. Rev Soc Bras Med Trop 31 (Supl. I): 132.

Rangel EF, Souza NA, Wermelinger ED, Barbosa AF 1984. Infecção natural de Lutzomyia intermedia (Lutz \& Neiva, 1912) em área endêmica de leishmaniose tegumentar no Estado do Rio de Janeiro. Mem Inst Oswaldo Cruz 79: 395396.

Rangel EF, Souza NA, Wermelinger ED, Barbosa AF, Andrade CA 1986. Flebótomos de Vargem Grande, foco de leishmaniose tegumentar no Estado do Rio de Janeiro. Mem Inst Oswaldo Cruz 8: 347-349.

Sabroza PC 1981. O Domicílio como Fator de Risco na Leishmaniose Tegumentar Americana. Estudo Epidemiológico em Jacarepaguá, Município do Rio de Janeiro, MSc Thesis, Escola Nacional de Saúde Pública-Fiocruz, Rio de Janeiro, 187 pp.

Shannon RC 1939. Methods for collecting and feeding mosquitoes in jungle yellow fever studies. Am J Trop Med Hyg 19: 131-140.

Sokal RR, Rohlf FJ 1995. Biometry: the Principles and Practice of Statistics in Biological Research, WH Freeman \& Co, New York, $887 \mathrm{pp}$.

Souza NA, Vilela ML Andrade-Coelho CA, Rangel EF 2001. The phlebotominae sand fly (Diptera:Psychodidae) fauna of two Atlantic Rain Forest Reserves in the State of Rio de Janeiro, Brazil. Mem Inst Oswaldo Cruz 96: 319-324.

Stolf HO, Marques AS, Marques MEA, Yoshida ELA, Dillion NL 1993. Surto de leishmaniose tegumentar americana em Itaporanga, São Paulo (Brasil). Rev Inst Med Trop São Paulo 35: 437-442.

Sudia WD, Chamberlain RW 1962. Battery-operated light trap, an improved model. Mosquito News 22: 126-129.

Taniguchi HH, Tolezano JE, Corrêa FMA, Moraes RHP, Veiga RM, Marassa AM 1991. Epidemiologia da leishmaniose americana no Estado de São Paulo, Brasil. 1. Composição da fauna flebotomínica no município de São Roque, região de Sorocaba. Rev Inst Adolfo Lutz 51: 23-30.

Young D, Duncan NA 1994. Guide to the identification and geographic distribution of Lutzomyia sandflies in Mexico, the West Indies, Central and South America (Diptera: Psychodidae). Mem Am Entomol Inst 54: 1-881. 
$\mathrm{L}$ intermedia and $\mathrm{L}$ whitmani in Rio de Janeiro - Nataly A Souza et al. 